\title{
High-Pressure Granulites From the Tetons: THE EARLIEST RECORD OF HIMALAYAN-STYLE TECTONICS IN THE WORLD
}

\author{
B. RONALD FROST $\downarrow$ GEOLOGY \& GEOPHYSICS \\ UNIVERSITY OF WYOMING $\uparrow$ LARAMIE
}

\section{$\downarrow \quad$ PROGRESS REPORT}

In August 2004 a field party from the University of Wyoming consisting of one faculty member, two graduate students, and one undergraduate student spent two weeks mapping the basement gneisses in the area around Moose Basin. During this project we mapped an area on the pass between Moose Basin and Camp Lake (which is just west of Grand Teton National Park) in detail, made detailed traverses along the head of the cirque for about $3 \mathrm{~km}$ southeast of the Park boundary, and collected 44 samples for petrology (Figure 1).

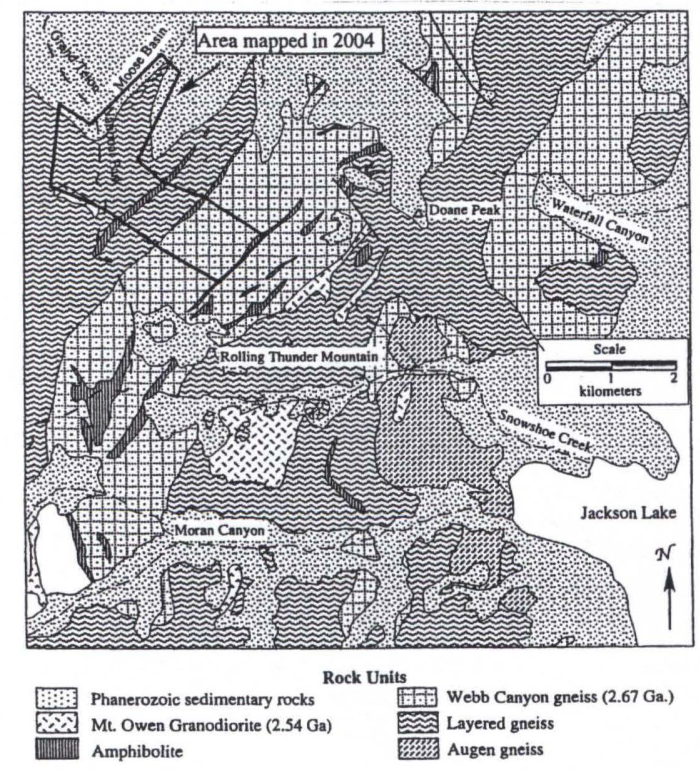

Figure 1. Geologic map of the northern portion of the Teton Range showing area studied in the summer of 2005.

\section{$\downarrow$ STRUCTURAL GEOLOGY:}

We recognized two distinct units in the area. One was a portion of the Layered Gneiss of Reed (1967) that consisted dominantly of interlayered mafic and pelitic gneiss with minor amounts of iron formation and metaperidotite. The other unit consists of the granitic Webb Canyon gneiss and a series of mafic dikes that have been intruded into it.

The layered gneiss The mafic and pelitic gneisses of the layered gneiss may have originally consisted of a single bedded sequence, with the pelitic gneiss deposited on the mafic gneiss. The layered aspect is a result of tight folding of this sequence. We recognized three periods of folding. The first event $\left(f_{1}\right)$ consists of tight isoclinal folds. The few axes of these folds that have been preserved plunge at moderate angles to the northeast. The second folding $\left(f_{2}\right)$ event is an isoclinal folding that produces the major structural features in the area. The folds from the $f_{2}$ event have a wavelength that isapproximately 30 meters and thus produces the layered appearance to the gneiss. The third event is an open folding event that carries with it no schistosity or lineation. We recognized a single synform from this event. From the crest of the range to Camp Lake the axial planes of the $f_{2}$ folds are horizontal with a gentle northward plunge. At the crest of the range the $f_{2}$ fold axes are abruptly folded to vertical with a plunge of $45^{\circ}$ to the north. We interpret the steeply dipping fold planes to mark the east limb of an open $f_{3}$ fold. The west limb, if it exists should lie west of Camp Lake. 
The Webb Canyon gneiss The Webb Canyon gneiss is a weakly foliated orthogneiss that lies structurally beneath the layered gneiss. The weak foliation in the Webb Canyon gneiss is not folded but has a strong lineation that plunges $45^{\circ}$ to the northeast, parallel to the trend of the $f_{2}$ fold axes in the overlying layered gneiss (Figure 2). The portion of the Webb Canyon gneiss mapped by Reed (1967) is relatively homogenous, with only a few amphibolite dikes. There is a 500 meter-wide band between the homogenous Webb Canyon gneiss and the layered gneiss that consists of Webb Canyon gneiss that has been intruded by a number of 3-10 meter wide gabbroic and dioritic dikes. These dikes are parallel to the foliation of the layered gneiss and were mapped as part of the layered gneiss by Reed (1967). Because they are lithologically distinct from the overlying layered gneiss and have not been folded, we conclude that they are part of the Webb Canyon igneous event.

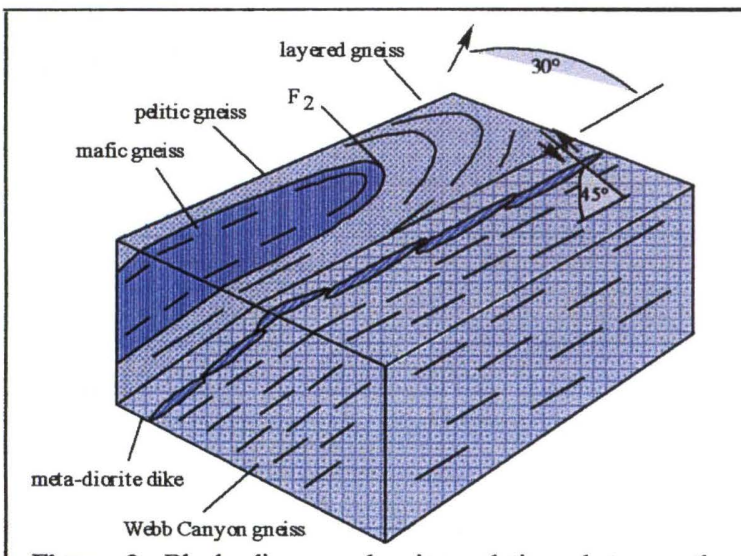

Figure 2. Block diagram showing relations between the layered gneiss and the Webb Canyon gneiss.
The pelitic rocks show a protracted history of retrogression and decompression. Kyanite is the major $\mathrm{Al}_{2} \mathrm{SiO}_{5}$ polymorph, although in many rocks it is rimmed by sillimanite. The kyanite grains lie along the lineations associated with both the $f_{1}$ and the $f_{2}$ folding events, indicating that much of the decompression occurred after these events. Most of the pelitic rocks have the assemblage quartz-biotitekyanite-garnet. Muscovite is absent, but so is $\mathrm{K}$ feldspar. This assemblage is stable at high pressures ( $>77$ kilobars) and at temperatures up to $700^{\circ} \mathrm{C}$ ) (Spear and Cheney, 1989). Cordierite is a widespread decompressive phase that forms rims around garnet, staurolite, kyanite, and sillimanite.

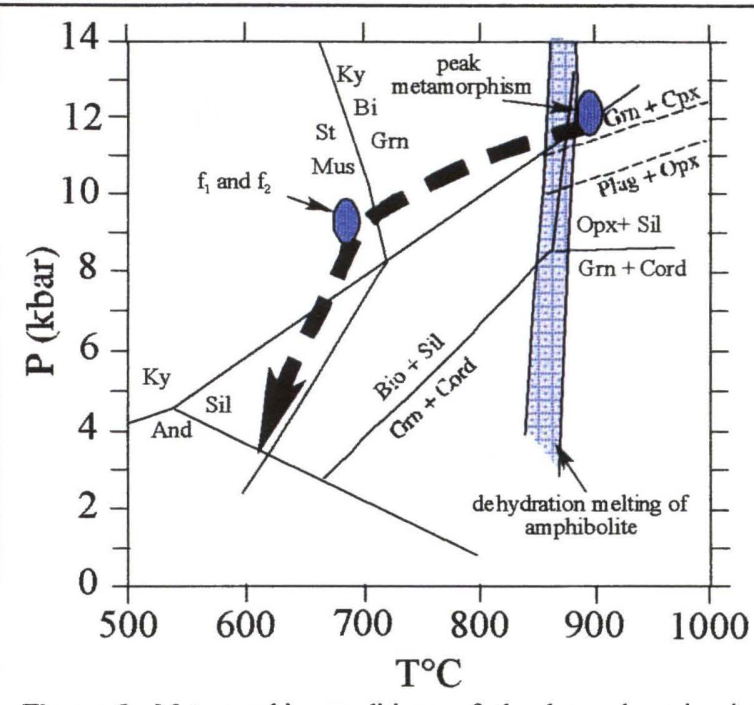

Figure 3. Metamorphic conditions of the layered gneiss in Moose Basin. Dashed arrow shows possible decompression path. Phase boundaries from Pattison et al. (2003), Spear and Cheney (1989) and Spear et al. (1999).

\section{$\downarrow$ PeTROLOGY:}

Where the outcrops of mafic gneiss are unusually wide (on the order of 100 meters or more) the mafic gneiss has a directionless fabric in the core of the outcrop that locally contains relict pyroxenes. In places these rocks also contain irregular garnetbearing, relatively felsic patches. We interpret these as records of a partial melting event that produced garnet. Such melting must have occurred at pressures of least 10 kilobars and temperatures of $850^{\circ} \mathrm{C}$ or higher (Pattison et al 2003) (Figure 3). Where the mafic gneiss forms thin layers and on the margins of the larger outcrops the rock has been hydrated to form a foliated amphibolite, which in many places is garnet-bearing. 
Our mapping last summer established that the Webb Canyon gneiss carries the same lineation as the $\mathrm{f}_{2}$ folds in the layered gneiss. This means that the Webb Canyon gneiss was intruded into the layered gneiss late in $f_{2}$ as the granulites were undergoing decompression. Because the Webb Canyon gneiss formed at ca. 2.67 Ga (Cornia, 2003), the highpressure metamorphism in the Tetons must have formed before $2.67 \mathrm{Ga}$. We do not know yet how much earlier this was. The $2.67 \mathrm{Ga}$ age of the major deformation in the Teton Range makes it coeval with the formation of the Mount Helen structural belt and emplacement of the Bridger batholith in the Wind River Range. This establishes for the first time that there is a connection between the Archean structures in the Wind River and the Teton Ranges.

\section{$\downarrow$ FURTHER WORK:}

We need to do considerable further work to establish the geologic context for the rocks we sampled last summer. In summer 2005 we intend to determine whether the Webb canyon gneiss that lies to the west of Camp Lake is west limb of the large $f_{3}$ fold we mapped last summer. We also intend to make a traverse across the Webb Canyon gneiss to study the contact between it and the eastern layered gneiss in the vicinity of Rolling Thunder Mountain. We suspect that the western layered gneiss is lithologically (and probably structurally) distinct from the layered gneiss in Moose Basin. If this is true then Webb Canyon gneiss probably intruded along thrust fault between the western and eastern belts of layered gneiss.

We also have considerable lab work to do. We have just begun on our study of the thermobarometry of the rocks. Although we have yet to find intact assemblages from the peak metamorphism, we have samples of both pelitic and amphibolitic gneiss that will help to determine quantitatively the decompression path followed by the rocks.

\section{Literature CITED}

Cornia, M.E. 2003. The Archean history of the Teton Range and surrounding areas, Wyoming and Idaho, M.S. thesis, University of Wyoming, Laramie, Wy. 192 p.

Pattison, D.R.M., T. Chacko, J. Farquhar and C.R.M. McFarlane. 2003. Temperatures of granulitefacies metamorphism: Constraints from experimental phase equilibria and thermobarometry corrected for retrograde exchange. Journal of Petrology, 44, 867-900.

Reed, J.C., Jr. 1967. Structure of Precambrian crystalline rocks in the northern part of the Grand Teton National Park, Wyoming. U.S.G.S. Professional Paper 475-C, article 60, p. C1-C6.

Spear, F.S. and J.T. Cheney. 1989. A petrogenetic grid for pelitic schists in the system $\mathrm{SiO}_{2}$ $\mathrm{Al}_{2} \mathrm{O}_{3}-\mathrm{FeO}-\mathrm{MgO}-\mathrm{K}_{2} \mathrm{O}-\mathrm{H}_{2} \mathrm{O}$. Contributions to Mineralogy and Petrology, 101, 149-164.

Spear, F.S., M.J. Kohn, and J.T. Cheney. 1999. P-T paths from anatectic pelites, Contributions to Mineralogy and Petrology, 134, 17-32. 